\title{
CHANGES IN PHYSICAL FITNESS AMONG HIGH GRADE SCHOOLGIRLS
}

\author{
Oksana Smirnoviené ${ }^{1}$, Rita Sadzevičien $\dot{e}^{2}$, Edita Maciulevičiene் $\dot{e}^{2}$ \\ „,Nemunas “ Secondary School', Kaunas, Lithuania \\ Lithuanian Academy of Physical Education²,Kaunas, Lithuania
}

\begin{abstract}
Research background and hypothesis. During the last five years Lithuanian long-term research related to the peculiarities of changes in physical fitness among 10-12 th -grade schoolgirls has not been found. Other research in Lithuania showed negative tendencies of physical fitness changes of Lithuanian schoolchildren and prevailing sedentary lifestyle.

Research aim was to determine peculiarities of change results in physical fitness among Kaunas schoolgirls $\left(10-12^{\text {th }}\right.$ grades $)$.

Research methods. The present research included $10^{\text {th }}$-grade schoolgirls $(\mathrm{n}=244)$ of Kaunas city who were at school during the research and were able to perform the necessary Eurofit tests: $10 \times 5 \mathrm{~m}$ Shuttle run, Standing Broad Jump, Sit ups in 30 seconds, 20 m endurance Shuttle run.

Research results. Changes in results of Eurofit tests performed from $10^{\text {th }}$ grade autumn to $12^{\text {th }}$ grade spring were different. Results of girls $\left(10-12^{\text {th }}\right.$-grade) in $10 \times 5 \mathrm{~m}$ shuttle run test did not change $(\mathrm{p}>0.05)$. Results of standing broad jump improved significantly in Grade $11(\mathrm{p}<0.05)$. Results in $20 \mathrm{~m}$ endurance shuttle run test improved in Grade 12 $(\mathrm{p}<0.05)$. Results in Sit ups in 30 seconds test improved in spring. Significant differences were found between 10 and $12^{\text {th }}$ grade schoolgirls spring Sit ups in 30 seconds test results, and 10 and $11^{\text {th }}$-grade autumn results.

Discussion and conclusions. Comparison of physical fitness of 10 and $12^{\text {th }}$-grade girls showed that it improved only in $20 \mathrm{~m}$ endurance shuttle run, in the $11^{\text {th }}$ grade explosive strength of schoolgirls significantly improved.
\end{abstract}

Keywords: changes in physical fitness, Eurofit tests, physical characteristics.

\section{INTRODUCTION}

$\mathrm{P}$ hysical fitness is an integral part of health and healthy lifestyle. Understanding physical fitness and knowledge of physical characteristics help children educators to successfully prepare the younger generation for happy life. That should help understand and improve schoolchildren themselves (Jaras, 1999; Puišienè, 2004; Skurvydas et al., 2006).

Decreased physical activity, high static loads and the resulting poor posture can affect the structural and functional changes in the growing human organism. Children grow and develop until their maturity, and during this complex process special and important changes take place in their organisms. Extremely important for child development are teenage years when the child begins to mature sexually because during this period tumultuous changes in all body systems take place. Exactly during this period the bodies of boys and girls sensitively react to loads. So, high physical loads at this age can disturb harmonious development of children (Tutkuvienè, 1995).

Measurements of physical fitness, access to information about the observed results and suggestions for improving physical fitness would motivate schoolchildren to come to the gyms more often, use sports equipment, do exercises in the fresh air, increase their physical activity, and thereby enrich their lives and improve their health (Volbekiene, Kavaliauskas, 2002; Corbin, Lindsey, 2007 ). 
During the last five years Lithuanian long-term research related to the peculiarities of changes in physical fitness among $10-12^{\text {th }}$-grade schoolgirls has not been found. Other research in Lithuania concerning physical fitness of schoolchildren in Lithuania were on physical activity and physical self-study (Volbekienè, Kavaliauskas, 2002; Batutis, 2003; Baublienè, 2003; Mozūrienè, Volbekiene, 2006). Negative tendencies in the changes physical fitness among Lithuanian schoolchildren and prevailing sedentary lifestyle were determined.

The aim of the study was to determine the peculiarities of changes results in physical fitness result among Kaunas schoolgirls (10-12 ${ }^{\text {th }}$ grades).

\section{RESEARCH METHODS}

Research object. The present research included $10^{\text {th }}$ grade schoolgirls of Kaunas city who were at school during the research and were able to perform the necessary Eurofit tests. The same girls took part in all their studies, from the $10^{\text {th }}$ to the $12^{\text {th }}$ grades. The total amount of subjects was 244 , we used the data of 230 girls as 14 girls did not complete the study due to illness, injury, or moving to another school. This group included the girls who had participated in sports activities for more than 1 year before $(n=47)$ or during $(n=38)$ the research period.

Organization of the research. The research was conducted in four secondary schools in Kaunas. The research was conducted from 2006 to 2009. The data were collected 2 times during the school year - in September and May. Long-term research from the $10^{\text {th }}$ grade autumn to the $12^{\text {th }}$ grade spring was conducted.

There were two weekly physical education lessons at school. During these lessons the testing was carried out. Researchers encouraged to perform the test accurately, quickly and consistently. The girls were not allowed to carry out preliminary test trials if test instructions did not include that. Eurofit tests for agility, explosive strength of leg muscles, strength endurance of waist muscles, endurance were carried out. The following tests were used:

- for running speed and agility $-10 \times 5 \mathrm{~m}$ Shuttle run;

- for explosive leg power - Standing Broad Jump;

- for trunk strength - Sit ups in 30 seconds;

- for cardiorespiratory endurance - $20 \mathrm{~m}$ endurance Shuttle run.
For testing Eurofit proposed test sequence was taken into account (during one physical education lesson the tests included Standing Broad Jump, Sit ups in 30 seconds, $10 \times 5 \mathrm{~m}$ Shuttle run. During the next lesson the girls performed $20 \mathrm{~m}$ endurance Shuttle run). Between the tests we made the necessary breaks in order to allow the organisms of children to recover (Volbekienè, Kavaliauskas, 2002).

Statistical analysis. All calculations were performed using „Microsoft Excel 2007“ program. The averages of tests, their standard deviations and percentage values were calculated for each investigated group. Reliability of result differences was assessed by Student's $t$ test. Statistical significance in this investigation was set at $\mathrm{p}<0.05$.

\section{RESEARCH RESULTS}

Research data showed that results of explosive leg power in $10^{\text {th }}-12^{\text {th }}$ grade girls were lower compared to the results of same test for Lithuanian girls in 1992 and 2002. Therefore, running speed and agility, trunk strength, cardiorespiratory endurance were better developed in our tested cohorts.

The change in the result of Eurofit tests performed from $10^{\text {th }}$ grade autumn to $12^{\text {th }}$ grade spring were different. Results of girls (10-12 ${ }^{\text {th }}$ grade) in $10 \times 5 \mathrm{~m}$ shuttle run test did not change ( $p>0.05)$. Results of standing broad jump improved significantly in Grade $11(\mathrm{p}<0.05)$ (Figure 1). Results in $20 \mathrm{~m}$ endurance shuttle run test improved in Grade $12(\mathrm{p}<0.05)$ (Figure 2). Sit ups in 30 seconds test results showed the tendency of improvement in spring. Significant differences were between 10 and $12^{\text {th }}$-grade spring Sit ups in 30 seconds test results compared to 10 and $11^{\text {th }}$ grade autumn results (Figure 3). However, comparing the $10^{\text {th }}$ grade better results (which were reached in spring) with the $12^{\text {th }}$ grade results, we did not define any changes.

We made a comparison of results of girls (from 10 to $12^{\text {th }}$ grade) in physical fitness tests as well (Figure 4). As a starting point we used autumn results of Grade 10. We can see that the biggest changes were in cardiorespiratory endurance results, in $12^{\text {th }}$ grade spring they were better by $6.06 \%$. Figure 4 shows that among girls' results of three physical fitness tests performed in $11^{\text {th }}$ grade autumn, comparing them wit the $10^{\text {th }}$ grade autumn level, only Standing Broad Jump results improved by $4.36 \%$. Results of $10 \times 5 \mathrm{~m}$ Shuttle run remained the same (not more then $1.5 \%$ ). 


\section{DISCUSSION}

Physical characteristics develop during the whole school age, but not at the same rate. Each physical characteristic has critical periods of development when its development is the most effective. The final formation of individual human organs and systems has different ending points (Ivaškienè, 2002). During maturation mobility increases speed, strength, accuracy, coordination and stamina of children. Interestingly, mobility matures in such sequence: "from the head towards the feet", i. e. first maturation is observed in muscles which are closer to the axis centre and then muscles of limbs, "from whole to parts", i. e. first movements mature and then the separate parts of body (Neumann, 2002). Total efficiency and development of individual physical characteristics of the girls stabilize at the age of 13-14 years, i. e. when they matured sexually (Malina et al., 2004). This phenomenon can be explained by increased weight (especially adipose tissue) and decreased movement (Volbekienè, Griciūte, 2007). There is also research (Malina et al., 2004), claiming that such consistent pattern of development of girls' mobility does not depend on race or on the environment. Presumably, this female peculiarity of maturation with its related deleterious effects (obesity, decline of physical fitness, etc.) can only be compensated by increased movement (special training, intensive physical exercises).

Our research showed that in the $10-12^{\text {th }}$ grades significant changes were found only in the results of endurance test. In the $11^{\text {th }}$ grade we found improvement in explosive leg power and fluctuation

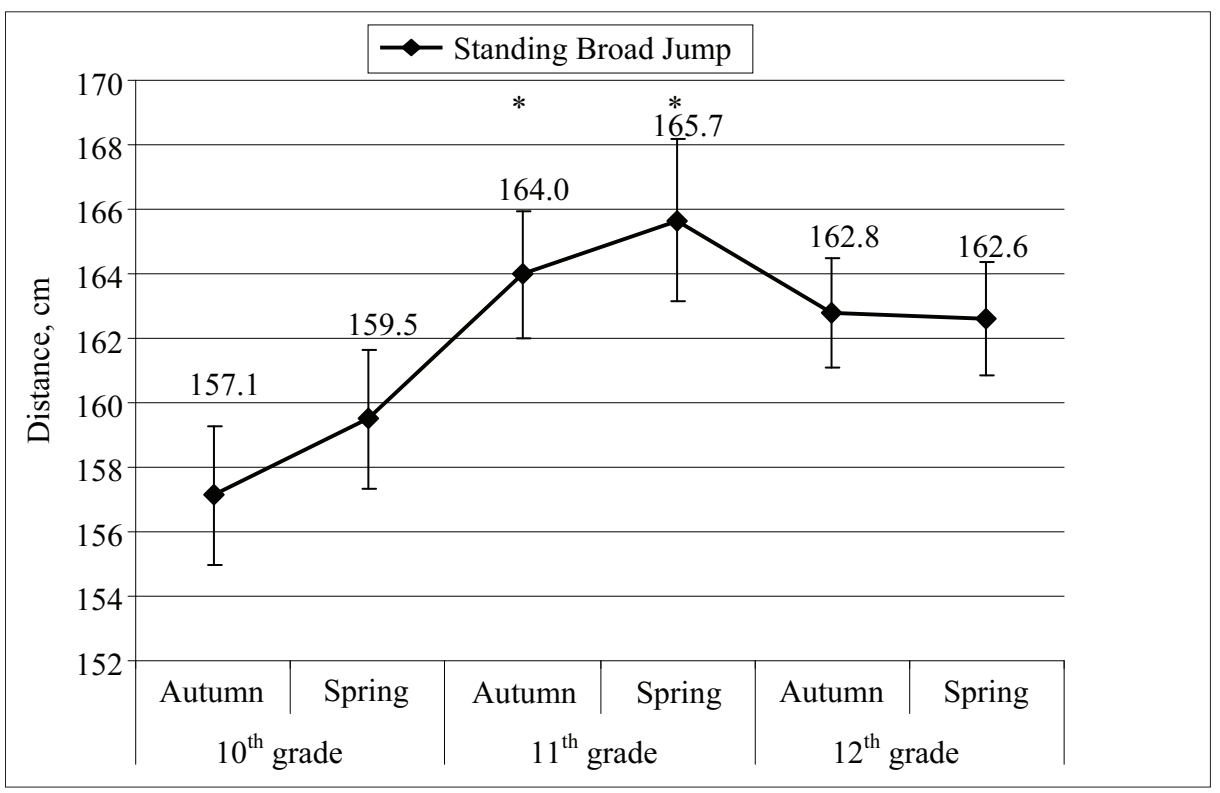

Figure 1. Changes in Standing Broad Jump test results

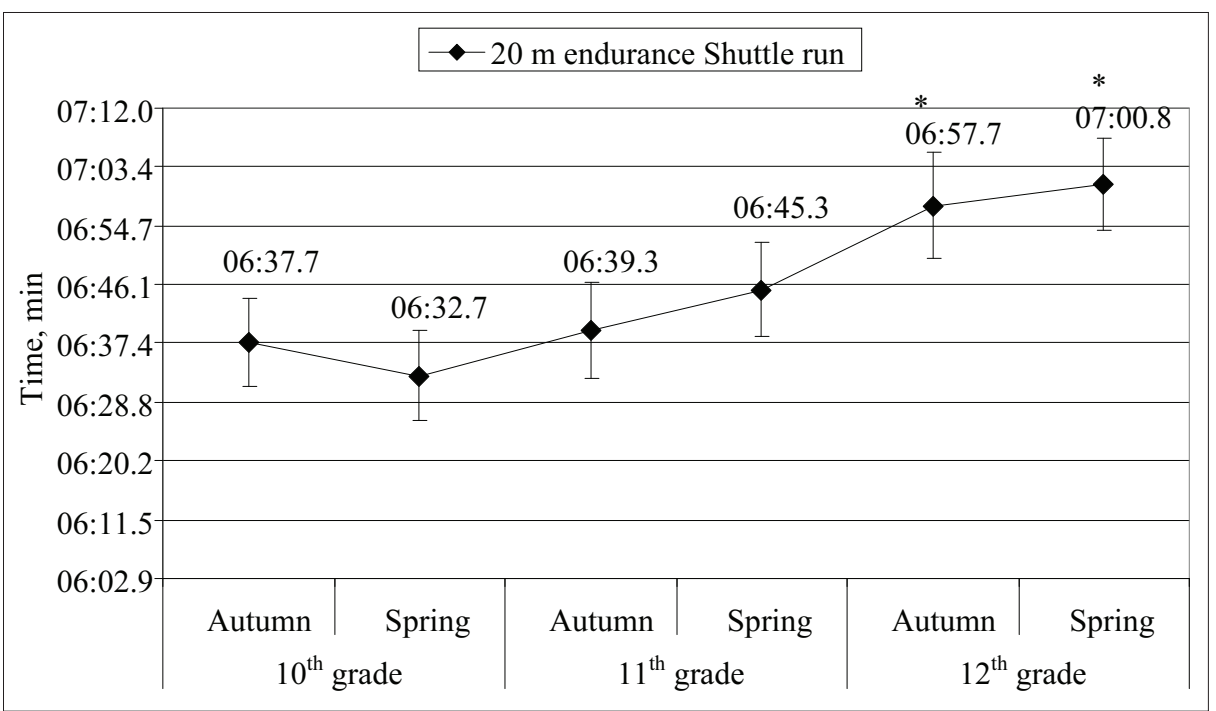

Note. $*-p<0.05$ compared to the 10th grade autumn and spring results.

Figure 2. Changes in $20 \mathrm{~m}$ endurance Shuttle run test results

Note. ${ }^{*}-\mathrm{p}<0.05$ compared to the $10^{\text {th }}$ grade autumn, spring and $11^{\text {th }}$ grade autumn results. 
Figure 3. Changes in Sit ups in 30 seconds test results

Note. $*-p<0.05$ compared to the 10 th and 11th grades autumn results.
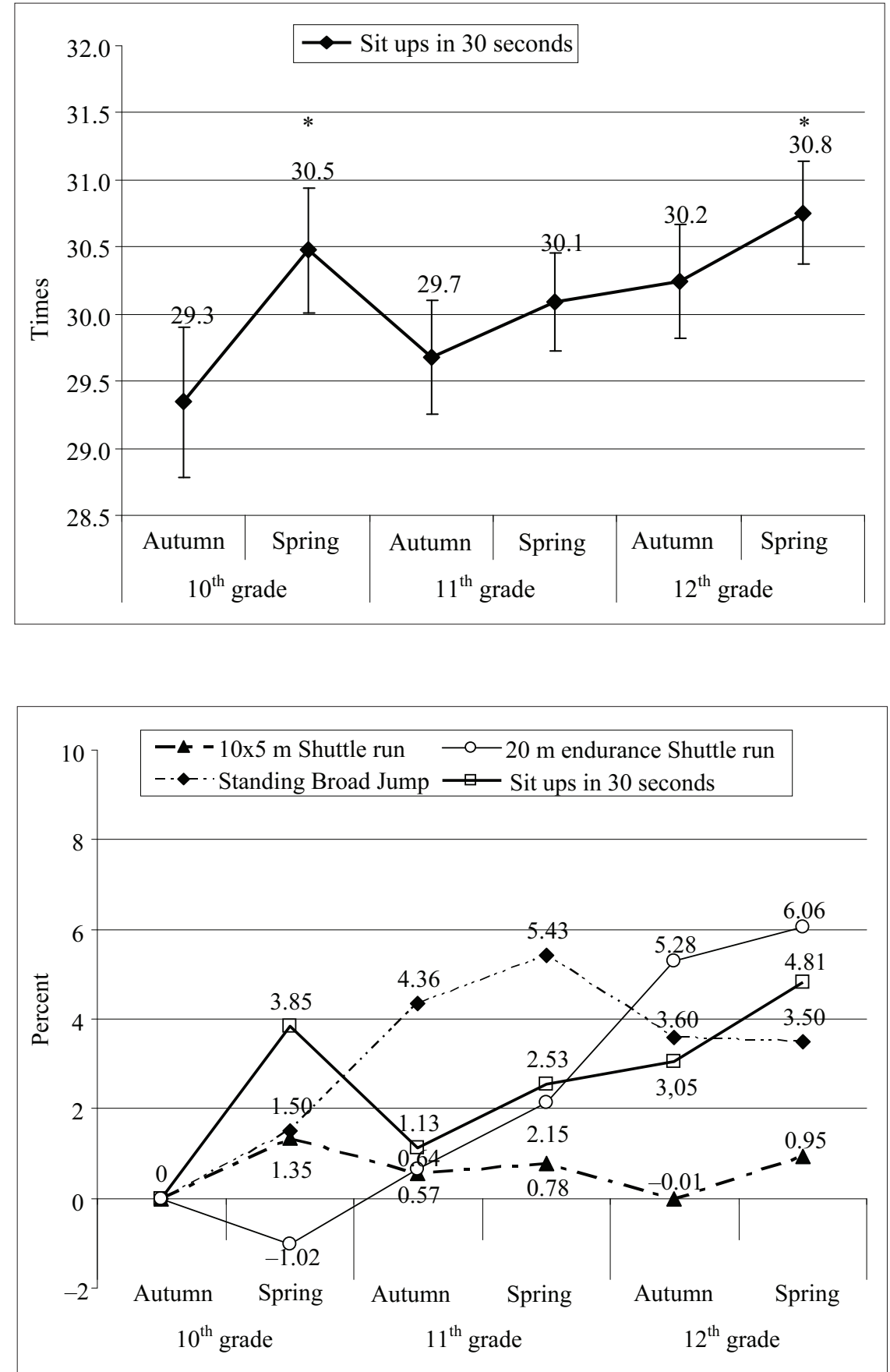

Figure 4. Comparison of changes in results in percent in the results of trunk strength. Comparing our findings with the ones by other authors we can see similar results. The research carried out with the girls of the eleventh grade showed that without additional special physical education program indicators of $11^{\text {th }}$ grade schoolchildren physical characteristics during the school year remained the same (Ivaškiené, Meidus, 2007). Girls' physical abilities more or less linearly improve from 6 to 14 years. Strength endurance of trunk muscles improves up to 14 years, and later it remains at the similar level (Malina et al., 2004). Girls' results of standing broad jump, which reflect explosive leg power, increase linearly up to 14 years. After 14 years of age, indicators of explosive leg power improve but at a slower rate (Malina et al., 2004). Agility of girls starts to improve from 5-8 years to 13-14 years, in older age the results of agility improve very slightly (Malina et al., 2004). In this case, our research revealed significant changes in the girls' agility results. Agility of girls from 10 $12^{\text {th }}$ grades spring never changed more than by $2 \%$. 
Capability of girls' cardiovascular system increases from 7 to 17 years of age, and during this period it increases more than twice (Armstrong, Welsman, 1994; Malina, Katzmarzyk, 2006). Our research also shows that girls' cardiorespiratory endurance improves. The last change was the highest than the one in other tests ever carried out, and it was $9.72 \%$.

Slowdown or stabilization of physical fitness indicators is related to biological changes during girls' maturation (i. e. sexual maturation, fat accumulation and body composition changes) or it is related to cultural factors (i. e. changes in social needs and expectations, pressure of contemporaries, lack of motivation or lack of opportunities to engage in physical activity-related activities). The interaction of biological and cultural factors influences the indicator curves (Malina et al., 2004; Volbekienè, Griciūtè, 2007).

\section{CONCLUSION AND PERSPECTIVES}

Comparison of physical fitness of the $10^{\text {th }}$ and $12^{\text {th }}$ grade girls, shows that it improves only in $20 \mathrm{~m}$ endurance shuttle run, in the $11^{\text {th }}$ grade explosive strength significantly improves. Further research is needed to determine the results of physical fitness influencing factors and find ways to encourage girls in high grades to improve physically.

\section{REFERENCES}

Amstrong, N., Welsman, J. (1997). Young People and Physical Activity. GB.

Batutis, O. (2003). Moksleiviu požiūris i fizinę saviugda ir jo ugdymo galimybés mokykloje: daktaro disertacijos santrauka. Kaunas: LKKA.

Baublienè, R. (2003). Asmenybès raida ir nuolatine saviugda. Kaunas: LKKA.

Corbin, C., Lindsey, R. (2007). Fitness for Life (Updated 5th Edition-Paper). Human kinetics.

Ivaškienè, V. (2002). Fiziniu ypatybiu lavinimas per kūno kultūros pamokas. Kaunas: LKKA.

Ivaškiene, V., Meidus, L. (2007). Physical fitness changes in girls from the 11 th grades promoting their physical self - development and training their best developed physical qualities. Ugdymas. Kūno kultūra. Sportas, 3 (66), 11-18.

Jaras, V. G. (1999). Kūno kultūros humanizmo ir demokratizavimo linkme. Vilnius: A. Varno PI.

Malina, M. R., Bouchard, C., Bar-Or, O. (2004). Growth, Maturation and Physical Education (2 ${ }^{\text {nd }}$ ed.). Champaign, IL: Human Kinetics.

Malina, R. M., Katzmarzyk, P. T. (2006). Physical activity and fitness in intenational growth standard for preadolescent and adolescent children. Food and Nutrition Bulletin, 27, 4, 295-313.

Mozūrienè, I., Volbekiene, V. (2006). Intervention to the program of comprehensive high school $11^{\text {th }}-12^{\text {th }}$ grade girls physical education: Model of integrated physical education. Sporto mokslo dabartis ir naujosios idejos: tarptautine moksline konferencija: praně̌imu tezès (pp. 93-94). Kaunas.

Numann, D. A. (2002). Kinesiology of Musculoskeletal System. USA: Mosby.

Puišienè, E. (2004). Kasdien judeti. Vilnius: Šiaurès Lietuva.

Skurvydas, A., Stonkus, S., Volbekienė, V. (2006). Kūno kultūra: geras ir gražus žmogus. Kaunas: LKKA.

Tutkuvienè, J. (1995). Vaiku augimo ir brendimo vertinimas. Vilnius: Vilspa.

Volbekienè, V., Griciūtė, A. (2007). Health-related physical fitness among schoolchildren in Lithuania: A comparison from 1992 to 2002. Scandinavian Journal of Public Health, 35, 3, 235-242.

Volbekiene, V., Kavaliauskas, S. (2002). Eurofitas. Fizinio pajegumo testai ir metodika. Lietuvos moksleiviu fizinio pajègumo rezultatai. 2-asis pataisytas ir papildytas leidimas. Vilnius: LSIC. 


\title{
VYRESNIŲJŲ KLASIŨ MERGAIČIŲ FIZINIO PAJĖGUMO KAITA
}

\author{
Oksana Smirnoviené $\dot{1}^{1}$ Rita Sadzevičiené2 $\dot{2}^{2}$ Edita Maciulevičienè ${ }^{2}$ \\ „Nemuno" viduriné mokyklal, Kaunas, Lietuva \\ Lietuvos kūno kultūros akademija², Kaunas, Lietuva
}

\begin{abstract}
SANTRAUKA
Tyrimo pagrindimas ir hipoteze. Lietuvoje per pastaruosius penkerius metus 10-12 klasiu mergaičiu fizino pajègumo kitimo ilgalaikių tyrimų nepavyko rasti. Netiesioginiai šių ypatumų tyrimai parodè, kad Lietuvos moksleivių fizinio pajëgumo kitimas turi neigiamų tendencijų ir tarp moksleivių vyrauja sėdima gyvensena.

Tikslas - nustatyti Kauno miesto mergaičiu fizinio pajègumo rezultatų kitimo ypatumus 10-12 klasejje.

Metodai. Tirtos Kauno miesto 10 klasès mergaitès $(\mathrm{n}=244)$, tyrimo metu buvusios mokykloje ir galinčios atlikti reikiamus Eurofito testus. Duomenys buvo registruojami 2 kartus per mokslo metus - rugsèjo ir gegužès mėnesiais. Ilgalaikis tyrimas pradètas 10 klasės rudenị ir tęsèsi iki 12 klasės pavasario. Moksleivès atliko Eurofito testus ( $10 \times 5 \mathrm{~m}$ bẻgimo šaudykle, šuolio į tolį iš vietos, „Sèstis ir gultis“, $20 \mathrm{~m}$ ištvermès bejgimo šaudykle).

Rezultatai. Nuo 10 klasès rudens iki 12 klasès pavasario mergaičiu skirtingų Eurofito testų rezultatų kaita buvo nevienoda. Tyrimas parodè, kad 10-12 klasèse reikšmingai pakito tik ištvermès testo rezultatai, o 11 klasėje pastebėtas staigiosios jëgos pagerejimas ir liemens jëgos rezultatų svyravimas.

Aptarimas ir išvados. Lyginant 10 ir 12 klasių mergaičių fizini pajëgumą nustatyta, kad jis pagerèja tik atliekant $20 \mathrm{~m}$ šaudyklinio bėgimo testą, o 11 klasėje reikšmingai pagerèja staigioji jëga.
\end{abstract}

Raktažodžiai: fizinio pajėgumo kaita, Eurofito testai, fizinės charakteristikos.

Gauta 2011 m. lapkričio $2 \mathrm{~d}$.

Received on November 2, 2011 